\title{
PENGARUH PENGATURAN TEMPAT DUDUK TERHADAP EFEKTIFITAS PEMBELAJARAN BAHASA INGGRIS DI PRODI ARSITEKTUR ITN MALANG
}

\author{
Maria Istiqoma \\ Dosen Prodi Teknik Geodesi, Fak. Teknik Sipil dan Perencanaan, ITN Malang \\ e-mail: maria istiqoma@lecturer.itn.ac.id \\ Tutut Nani Prihatmi \\ Dosen Prodi Teknik Mesin, Fak. Teknologi Industri, ITN Malang \\ e-mail: tututnani@lecturer.itn.ac.id
}

\begin{abstract}
ABSTRAK
Pengaturan tempat duduk merupakan salah satu komponen penting dalam pengelolaan kelas dalam pembelajaran Bahasa Inggris yang diharapkan mampu meningkatkan terjadinya pembelajaran yang efektif. Tujuan dari penelitian ini adalah untuk mengetahui pengaruh pengaturan temp at duduk terhadap efektifitas pembelajaran Bahasa Inggris di Prodi Arsitektur ITN Malang serta model pengaturan tempat duduk yang yang paling efektif untuk pembelajaran Bahasa Inggris. Pendekatan yang digunakan adalah analisis ragam (ANOVA). Data diperoleh dari nilai tes standar dengan sampel 75 orang mahasiswa Arsitektur ITN Malang angkatan 2017 yang mengambil mata kuliah Bahasa Inggris pada semester ganjil 2017/2018. Hasil penelitian menunjukkan bahwa ada pengaruh penataan tempat duduk dalam meningkatkan nilai test mahasiswa, dan Formasi Corak Tim adalah penataan tempat duduk yang paling efektif.
\end{abstract}

Kata Kunci: pengaturan tempat duduk, pembelajaran efektif, Bahasa Inggris

\begin{abstract}
Seating arrangement is one of the important component in managing an English class which is expected to enhance an effective learning. The aims of this research is to know the influece of seating arrangement toward an English learning effectivity in Architecture Department and to determine the most effective model of seating arrangements applied. The approach employed in this research was ANOVA. Data was gained from standardized test scores of 75 samples of Architecture Department students taking an English subject in academic year 2017/2018. The result of this research showed that there was an influence of seating arrangements in LI Qa ci F sVuJLI Vs' test scores and it was learned that Team Formation is the most effective seating arrangement.
\end{abstract}

Keywords : seating arrangements, effective learning, English 


\section{PENDAHULUAN}

Dalam proses pembelajaran Bahasa Inggris, mahasiswa Arsitektur dituntut untuk mampu menguasai dan menggunakan keempat keterampilan utama dalam Bahasa Inggris yaitu listening, reading, speaking, dan writing. Dengan tuntutan yang besar tentang output skill mahasiswa Arsitektur di dalam memasuki Masyarakat Ekonomi Asia (MEA), dosen Bahasa Inggris diharapkan mampu untuk menemukan dan menggunakan teknik atau metode yang paling tepat untuk mengelola kelas dan mendukung proses terjadinya kegiatan belajar mengajar yang efektif (Widyarani, 2011). Dalam tata kelola ruangan kelas saat ini, sering dijumpai penataan kelas secara standar, yaitu meja dan kursi ditata secara berbaris dari depan sampai belakang (in rows). Sistem pengaturan tempat duduk standar semacam ini diasumsikan memungkinkan terjadinya hambatan-hambatan di dalam proses pembelajaran di kelas. Dalam pengaturan kelas standard ini, dosen menjadi titik fokus pandangan mahasiswa di depan kelas yang berperan sebagai pembicara utama, sementara mahasiswa lebih berperan sebagai pendengar pasif atau fokus bekerja secara individu. Akibatnya, pembelajaran di dalam kelas menjadi proses take (mahasiswa) and give (dari dosen). Dalam hal ini, kemampuan mahasiswa dalam mengeksplorasi ketrampilan untuk berinteraksi dengan menggunakan kemampuan berbicara mereka (Speaking Skill) menjadi terbatasi, dimana pembelajaran Bahasa Inggris menuntut mereka menggunakan Bahasa Inggris secara aktif dan sering di dalam kelas (Language exposure).

Maka dari itu, pengaturan tempat duduk merupakan salah satu komponen yang penting dalam proses pembelajaran karena penataan tempat duduk yang efektif memungkinkan mahasiswa untuk mendapatkan kelebihan-kelebihan dalam proses pembelajaran Bahasa Inggris, antara lain aksesibilitas, mobilitas, dan interaksi (Sudrajat, 2008). Dengan latar belakang permasalahan tersebut, tujuan penelitian ini untuk mengetahui apakah pengaturan tempat duduk berpengaruh terhadap efektifitass pembelajaran Bahasa Inggris dan juga untuk mengetahui model pengaturan tempat duduk yang paling efektif untuk pembelajaran mata kuliah Bahasa Inggris pada program studi Arsitektur ITN Malang dengan membandingkan 3 (tiga) formasi pengaturan tempat duduk, yaitu formasi kelas tradisional NHb1)D1)L kHL1)N kPntrPL, FPrm1)NL “U”,I L1)n UPr1)V TLm8 


\section{TINJAUAN PUSTAKA}

Pengelolaan kelas merupakan upaya yang dilakukan oleh dosen dalam menciptakan lingkungan pembelajaran yang kondusif melalui kegiatan pengaturan pembelajar dan barang atau fasilitas pembelajaran sebagai upaya untuk menciptakan, memelihara tingkah laku siswa yang dapat mendukung proses pembelajaran (Luwesty, 2017:9). Kelas sebagai pusat pembelajaran memungkinkan dosen untuk mengelola semaksimal mungkin dalam rangka penyelesaian masalah yang ditemui, dan untuk mencapai tujuan pembelajaran. Mayoritas penelitian terdahulu menyatakan bahwa pengelolaan kelas yang baik akan menghasilkan interaksi belajar mengajar yang baik pula. Dengan demikian tujuan pembelajaran dapat dicapai secara efektif. Salah satu contoh, Winzer (dalam Winataputra, 2003: 9-21) menyatakan bahwa penataan lingkungan kelas yang tepat akan berpengaruh terhadap tingkat keterlibatan dan partisipasi siswa dalam proses pembelajaran.

\subsection{Penataan Tempat Duduk}

Dalam tata kelola kelas, penataan tempat duduk adalah salah satu pengelolaan kelas yang mudah dilakukan karena tidak memakan waktu lama dalam persiapannya. Dengan penataan tempat duduk, pengelolaan kelas dapat dilaksanakan dengan lebih baik apabila mengetahui kelebihan dan kekurangan dari masing-masing formasi tempat duduk. Terdapat beberapa pilihan tempat duduk yang bisa disesuaikan dengan kebutuhan mahasiswa dan tujuan pembelajaran. Pada beberapa penelitian sebelumnya, penataan tempat duduk relatif memberikan pengaruh yang besar dibandingkan penataan fisik kelas lainnya.

Winataputra (2005:21) menyatakan bahwa pengaturan tempat duduk berpengaruh terhadap jumlah waktu yang digunakan siswa untuk menyelesaikan tugas yang diberikan. Penataan tempat duduk siswa diasumsikan berperan besar dalam membantu menciptakan proses pembelajaran yang sesuai dengan tujuan pembelajaran yang ingin dicapai. Loisell (dalam Winataputra, 2003) mengemukakan 7 bentuk pengelolaan tempat duduk dalam kelas yaitu: 1. Formasi Huruf U, 2. Kelas Tradisional, 3. Formasi Corak Tim, 4. Meja Konferensi, 5. Lingkaran, 6. Susunan Chevron, 7. Auditorium.

Dalam penelitian ini ada 3 (tiga) formasi yang diteliti yaitu: Formasi Huruf U, Kelas Tradisional (sebagai kelas kontrol) dan Formasi Corak Tim. 


\subsubsection{Formasi Huruf $U$}

Pada Formasi huruf $U$, susunan meja dan kursi diatur seperti huruf $U$. Tempat duduk dosen bisa diletakkkan di ujung huruf $U$ atau berada ditengahnya dengan membiarkan bagian tengah kosong, sehingga tipe layout tempat duduk ini mendukung interaksi langsung antara dosen dan mahasiswa, dan juga antara mahasiswa dan teman sekelasnya. Formasi ini dapat digunakan untuk berbagai tujuan pembelajaran seperti diskusi kelas, diskusi grup, ceramah, presentasi, dan sebagainya. Dalam aplikasinya, kelas berinteraksi dalam format kelompok yang besar tetapi tetap memberikan peluang untuk dosen berinteraksi dengan mahasiswa satu demi satu, serta mahasiswa tetap bisa berinteraksi atau saling bertatap muka tanpa halangan, walaupun ada berberapa sudut yang tidak langsung bertatap muka sekaligus, selain itu jenis formasi $U$ memungkinkan mahasiswa bisa mengerjakan tugas langsung dari tempat duduknya (Istiqoma, 2017).

\subsubsection{Kelas Tradisional}

Model penataan tempat duduk ini adalah yang paling umum digunakan di seluruh dunia yang memungkinkan para siswa duduk berpasangan dalam satu meja dengan dua kursi. Model ini digunakan dari Sekolah Dasar hingga Sekolah Menengah Atas dan bahkan digunakan pada Perguruan Tinggi. Model ini sangat membatasi proses pembelajaran terutama dalam hal mobilitas mahasiswa dan dosen dan interaksi antar mahasiswa. Mahasiswa yang kurang aktif akan memilih untuk duduk di bagian belakang yang paling jauh dari pengajar.

\subsubsection{Formasi Corak Tim}

Formasi ini mengelompokkan meja-meja yang diatur dengan bentuk setengah lingkaran, masing-masing meja terdiri dari dua kursi di sisi kanan dan kiri yang memungkinkan mahasiswa bisa saling berhadap-hadapan. Dengan pengaturan ruang kelas ini, memungkinkan dosen untuk melakukan interaksi timtim yang ada di dalam kelas. Mahasiswa dapat memutar kursi melingkar menghadap ke depan ruang kelas untuk melihat dosen atau papan di depan kelas dengan mudah. Dengan pengaturan tempat duduk ini mahasiswa dengan mudah melakukan diskusi grup dengan teman satu meja. 


\subsection{Konsep Pembelajaran Efektif}

Sutikno (2007:49) menyatakan bahwa pembelajaran efektif adalah suatu pembelajaran yang memungkinkan siswa untuk belajar dengan mudah, menyenangkan, dan dapat membantu untuk mencapai tujuan pembelajaran sesuai dengan harapan. Pembelajaran dirancang sedemikian rupa agar mahasiswa nyaman dan senang dalam mengikuti proses pembelajaran tersebut. Pembelajaran efektif memudahkan mahasiswa mempelajari keterampilan, nilai, konsep, dan cara berinteraksi dengan sesama, atau hasil belajar yang diinginkan.

Berkaitan dengan penjelasan tersebut, dalam rangka menemukan pengaruh penataan tempat duduk terhadap pembelajaran efektif mata kuliah Bahasa Inggris, penulis mengajukan hipotesa sebagai berikut:

$\mathrm{Ho}=$ tidak ada pengaruh yang signifikan dari penataan tempat duduk terhadap pembelajaran efektif mata kuliah Bahasa Inggris pada Program Studi Arsitektur ITN Malang.

$\mathrm{Ha}=$ ada pengaruh yang signifikan dari penataan tempat duduk terhadap pembelajaran efektif mata kuliah Bahasa Inggris pada Program Studi Arsitektur ITN Malang.

\section{METODE PENELITIAN}

Penelitian ini menggunakan pendekatan kuantitatif yang menggunakan metode analisis ragam atau Analysis of Variance (ANOVA). ANOVA merupakan model statistik yang digunakan untuk menganalisis perbedaan rata-rata antara kelompok dan prosedur terkait, seperti variasi antara kelompok. Dalam ANOVA ini hanya ada satu hipotesis yang digunakan yaitu hipotesis dua arah (two tail hypothesis). Artinya hipotesis ini ingin mengetahui apakah ada perbedaan rata-rata atau tidak, dengan ketentuan jika signifikansi $>0,05$ maka Ho diterima, sebaliknya jika signifikansi $<0,05$ maka Ho ditolak. Metode pengumpulan data menggunakan metode kuantitatif yaitu dokumentasi nilai tes berupa standardized test dengan total 200 soal meliputi listening, grammar, dan reading skill. Pengolahan data dilakukan dengan bantuan aplikasi IBM SPSS statistik versi 24.

Dari total 135 mahasiswa pada program studi Arsitektur ITN Malang angkatan 2017, 75 mahasiswa digunakan sebagai sampel melalui Cluster Random Sampling, yaitu 25 mahasiswa dari masing-masing kelas A, B, dan C. Variabel yang terdapat dalam penelitian ini adalah pengaturan tempat duduk sebagai variabel bebas $(X)$ dan nilai pembelajaran Bahasa Inggris sebagai variabel terikat $(Y)$.

Data yang diambil dari penelitian ini adalah hasil nilai test dari masingmasing dua pengaturan tempat duduk yang terpilih, yaitu formasi kelas 
tradisional sebagai kelas kontrol, formasi "U" sebagai kelompok Varian I, dan formasi corak tim sebagai kelompok Varian II dimana masing-masing kelas terdiri dari 25 mahasiswa yang akan dijadikan sampel.

\section{HASIL DAN PEMBAHASAN}

Dalam pengolahan data, penelitian ini menggunakan Software SPSS for Windows versi 24 untuk mendeskripsikan dan merangkum data dalam bentuk tabel distribusi frekuensi. Dalam ANOVA, terlebih dulu dilakukan Uji Asumsi Normalitas untuk menentukan apakah data yang dikumpulkan memiliki distribusi normal dan juga dilakukan Uji Asumsi Homogenitas untuk mengetahui apakah beberapa varian dalam penelitian ini adalah sama atau tidak. Hasil uji menggunakan software SPSS ditampilkan pada Gambar 1 dan Gambar 2.

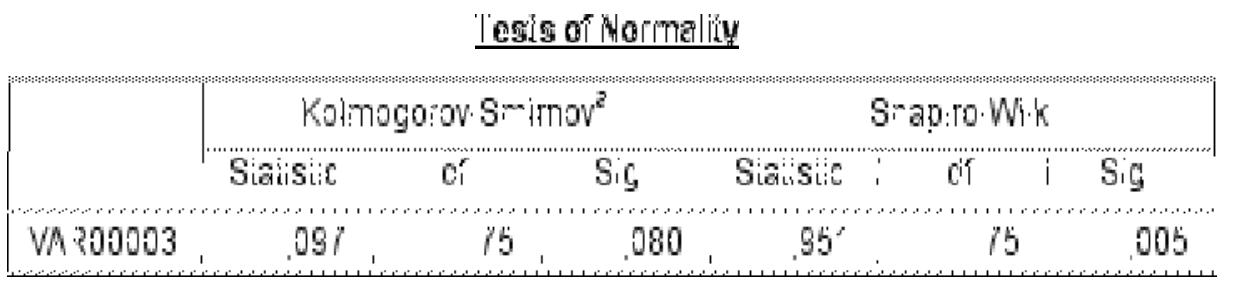

a. I..lliafors Signiíicance Correction

Gambar 1.

Hasil Uji Normalitas

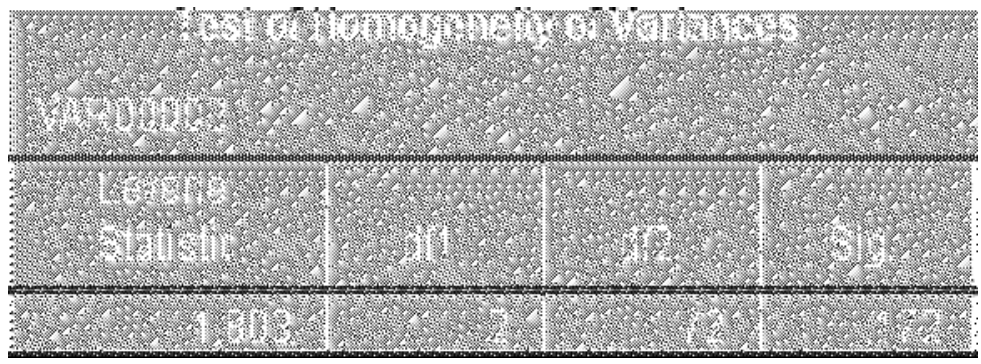

Gam bar 2.

Hasil Uji Homogenitas

Dengan hasil uji normalitas pada Gambar 1 dan Gambar 2 yang menunjukkan nilai signifikansi sebesar 0,080 dan homogenitas sebesar 0,172 , dapat disimpulkan bahwa data yang diuji telah terdistribusi normal dan homogen. 
Langkah berikutnya adalah melakukan pengujian one way ANOVA untuk mengetahui perbedaan rata-rata ketiga variasi tersebut. Pada penelitian ini, terdapat tiga variasi yang digunakan yaitu Varian I kelompok )RUPDsV LI" 'LIILI 9n II kDloLI ,, ok HorRk Sim L \& kelaN I 7LPLI siDnaLI NHsil pengujian ditampilkan dalam Gambar 3.

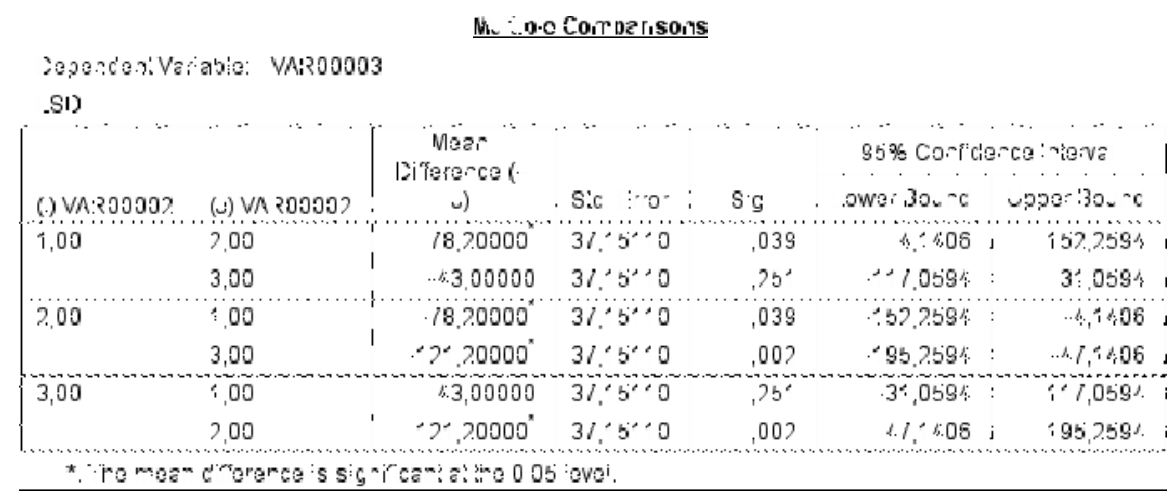

Gam bar 3.

Hasil Uji One Way ANOVA

Dari hasil uji di atas, dengan nilai signifikansi sebesar 0,039 yaitu $>0$ 05 d keGahui baDKX El EDKsi " L RUn D Vral TiLI (vDriEl i R U Dn L LP LI illki perbedaan rata-rata. Formasi Corak Tim dan konvensional (variasi 2 dan 3) memiliki perbedaan rata-rata dengan nilai 0,002 yaitu $<0,005$ yang berarti tidak PHPiliki NLLI SdHUE yGDg QLI ifikanLI VLJQLIL "D" LE RUnvDVsiLI al (variasi 1 dan 3) memiliki nilai signifikansi sebesar 0,251 yang berarti $>0,05$ sehingga ada perbedaan yang signifikan.

Hasil tes setelah dilakukan pembelajaran Bahasa Inggris yang berbeda penetaan tempat duduk pada kelas Varian I, kelas Varian II dan kelas kontrol ditunjukkan oleh Tabel 1.

Tabel 1.

Deskripsi Data Hasil Tes

\begin{tabular}{lcccc}
\hline Kelas & N & Minimum & Maximum & Mean \\
\hline Varian I (formasi U) & 25 & 70 & 590 & 214,6 \\
Varian II (formasi corak tim) & 25 & 100 & 590 & 335,8 \\
Varian III (konvensional) & 25 & 100 & 510 & 292,8 \\
\hline
\end{tabular}

Tabel 1. menunjukkan bahwa setelah melakukan penataan tempat duduk dalam pembelajaran Bahasa Inggris, mahasiswa Program Studi Arsitektur ITN Malang kelas Varian I mempunyai rata-rata 214,6 dengan nilai tertinggi 590 , dan nilai terendah 70 . Pada kelas Varian II rata-rata nilai 
adalah 335,8 dengan nilai tertinggi 590 , nilai terendah 100 . Sedangkan pada kelas Varian III didapat nilai rata-rata sebesar 292,8 dengan nilai tertinggi 510, dan nilai terendah 100. Secara umum hasil belajar pada kelas Varian I, kelas Varian II dan kelas kontrol tidak jauh berbeda yaitu sebagian besar dalam kategori cukup. Pada kelas Varian II dan kelas kontrol, tidak ditemukan adanya nilai kurang dari 100. Temuan tersebut menunjukkan bahwa baik kelas Varian I, kelas Varian II maupun kelas kontrol setelah diberikan penataan tempat duduk sudah memiliki pemahaman Bahasa Inggris dalam kategori Cukup dan Baik, dan hanya 8\% yang mendapatkan nilai di bawah 100 yaitu pada Varian I seperti yang ditampilkan pada tabel 2 berikut ini:

Tabel 2.

Distribusi Kategori Hasil Tes

\begin{tabular}{|c|c|c|c|c|}
\hline Rentang Skor & Kriteria & Varian I & Varian II & Kontrol \\
\hline $500-700$ & $\begin{array}{c}\text { Sangat } \\
\text { baik }\end{array}$ & $4 \%$ & $24 \%$ & $4 \%$ \\
\hline $300-500$ & Baik & $16 \%$ & $28 \%$ & $44 \%$ \\
\hline $100-300$ & Cukup & $72 \%$ & $48 \%$ & $52 \%$ \\
\hline$<100$ & Kurang & $8 \%$ & $0 \%$ & $0 \%$ \\
\hline
\end{tabular}

Untuk lebih jelasnya deskripsi kategori hasil belajar setelah dilakukan pengaturan formasi tempat duduk dapat disajikan dalam histogram seperti pada gambar 4 dibawah ini:

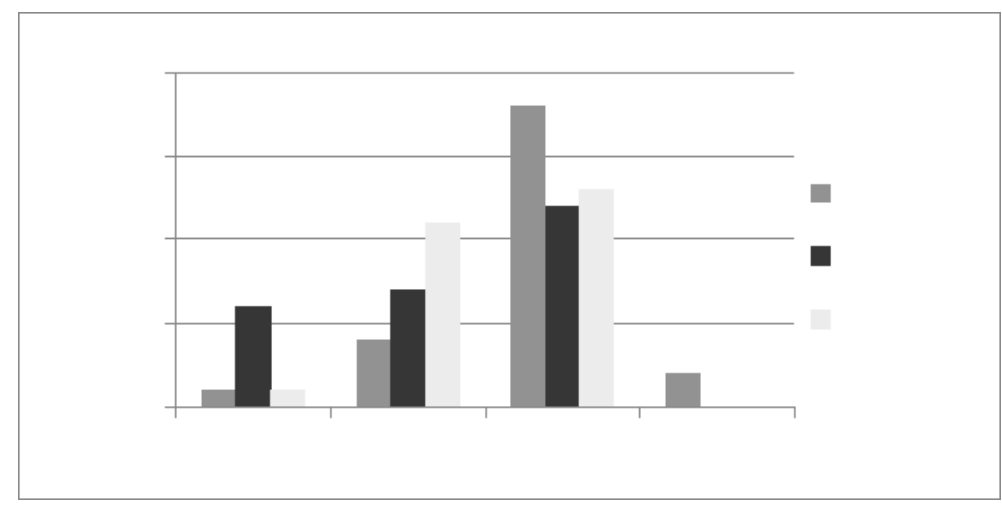

Gam bar 4.

Histogram Distribusi Kategori Hasil test dalam persen 
Dari hasil tersebut dapat disimpulkan bahwa dengan materi pembelajaran yang VDPD,LILI SaHaaD tempQLI duHPk foRmI si "G" NLI CURak Tim efektif dalam meningkatkan nilai test mahasiswa dalam standardized test, dan Formasi Corak Tim adalah penataan tempat duduk yang paling efektif dalam meningkatkan nilai tes mahasiswa. Dengan demikian Hipotesa Ha yang menyatakan terdapat pengaruh dari penataan tempat duduk terhadap efektifitas pembelajaran Bahasa Inggris pada Prodi Arsitektur ITN Malang dapat diterima, dan Ho ditolak.

\section{KESIMPULAN DAN SARAN}

Kesimpulan dan saran dari hasil studi ini adalah sebagai berikut:

1. 3 HnaDaaD tQLI atHdPSDk N RXasi ${ }^{\mathrm{N}} \mathrm{L}$ dan Formasi Corak Tim memiliki perbedaan yang signifikan dalam hasil tes mahasiswa.

2. Penataan tempat duduk Formasi Corak Tim memberikan hasil tes yang leHiE tiKLgi LaRJJLLI GpDULtaDn DoISHnsioWal DanLI NoRQasi " $U$ VL

3. Saran yang dapat diberikan bagi Program Studi Arsitektur Institut Teknologi Nasional Malang untuk dapat memanfaatkan hasil penelitian ini untuk melakukan pengaturan tempat duduk sesuai dengan tujuan pembelajaran yang ingin dicapai.

4. Penelitian selanjutnya dapat meneliti formasi penataan tempat duduk yang belum tercantum pada penelitian ini dan faktor-faktor yang menyebabkan terjadinya perbedaan hasil tes.

\section{DAFTAR PUSTAKA}

Akhmad Sudrajat. 2008. Teknik Pengelolaan Kelas. https://akhmadsudrajat.wordpress.com. diakses Januari 19, 2017.

Azwar, Saifudin. 1998. Metode Penelitian, Cet. 1. Yogyakarta: Pustaka Pelaja

Hadi, Sutrisno. Metodologi Reaserch I, (Yogjakarta: Andi Offset, 1989).

Istiqoma, Maria. 2017. Preliminary Study: Eksplorasi Layout Tempat Duduk untuk Pembelajaran Bahasa Inggris di Program Studi Arsitektur. Malang: Spectra.

Lie, Anita. $\quad$ 2007. Cooperative Learning (Memperaktikkan Cooperatif

Learning di Ruang-ruang Kelas). Jakarta: PT Grasindo

Luwesty, Anisa. 2017. KLHQgar7hSKLI aHaaDSFDDQas RUPDatS $7 d 7 P S^{D} U^{4} S$

Terhadap Peningkatan Motivasi Belajar Pada Mata Pelajaran Sejarah Siswa Kelas X lis Sma Negeri 3 Kotabumi Lampung Utara Tahun Ajaran 2015/2016. Unpublished skripsi. Bandar Lampung: Universitas Lampung.

Prihatmi, Tutut Nani. 2017. English Academic Writing Bagi Mahasiswa di Institut Teknologi Nasional Malang: Hambatan dan Solusi. Seminar 
Nasional Inovasi dan Aplikasi Teknologi di Industri 2017. Malang: LPPM ITN Malang.

Slavin, R.E. 2008. Educational Psychology. Jakarta: PT. Indeks.

Sugiharto, Toto. 2009. Analisis Varians. Jakarta: Universitas Gunadarma.

Sutikno, Sobry. 2007. Menggagas Pembelajaran Efektif dan Bermakna. Mataram: NTP Press.

Trianto. 2009. Mendesain Model Pembelajaran Inovatif Produktif. Jakarta: Prenada Media Group.

Udin S. Winataputra. 2003. Strategi Belajar Mengajar. Jakarta: Universitas Terbuka Departemen Pendidikan Nasional

Widyarini, Diana. 2011. Pengaruh Pengelolaan Kelas terhadap Pembelajaran Efektif pada Mata Pelajaran IPS di SMP Al-Mubarok Pondok Aren Tangerang Selatan. Unpublished Skripsi. Jakarta: Universitas Syarif Hidayatullah Jakarta

Winarsunu, Tulus. 2002. Statistik dalam Penelitian Psikologi dan Pendidikan. Malang: UMM Press. 